\title{
Life Style Modification Modulates Adhesive Molecules and Depression Among Saudi Type 2 Diabetic Patients
}

\author{
Mohammed H Saiem Al Dahr* \\ Department of Medical Laboratory Technology,King Abdulaziz University, Saudi Arabia
}

Submission: June 01, 2018; Published: July 17, 2018

*Corresponding author: Mohammed H Saiem Al Dahr, Department of Medical Laboratory Technology, Faculty of Applied Medical Sciences, King Abdulaziz University, P.O. Box 80324, Jeddah, 21589, Saudi Arabia, Email: mdahr@kau.edu.sa

Abstract

Background: Globally, type 2 diabetes (T2DM) can be considered as one of the most common health-related problem and it is considered as a cardiovascular disorders risk factor.

Objective: This study aimed to detect the influence of weight reducing program on adhesive molecules and depression among Saudi patients with T2DM.

Methods: One hundred obese Saudi patients with T2DM enrolled in two groups, group (A) received aerobic exercises \& diet regimen, while group (B) considered as a control group and received no exercise intervention or diet control for 3 months. Assessment of adhesive molecules and depression were done before and at the end of the project.

Results: Results of group (A) stated that mean values of BMI, ICAM-1, VCAM-1, E-selectin, BDI and POMS significantly decreasedin addition to significant increase in the mean value of RSES as result of weight reducing program, where parameters of group (B) displayed non-significant variations. Additionally, no significant differences found between both groups in all parameters $(\mathrm{P}<0.05)$.

Conclusion: Life style modification led to weight loss which modulates depression and adhesive molecules in obese type 2 diabetics.

Keywords: Type 2 diabetes; Obesity; Adhesive molecules; Depression; Weight reduction

\section{Introduction}

Globally, diabetes mellitus affects about 365millions of subjects by 2030[1]. Type 2 diabetes (T2DM) is considered a cardiovascular disorders risk factor [2]. Obesity is a state of excessive adipose tissue mass caused by increased size and number of adipocytes[3]. Mortality rate due to cardiovascular disorders is higher among patients with diabetes [4] due to dyslipidemia [5,6] and hypertension [7].

Adipose tissue secretes some chemical materials include adipocytokines which are locally and systemically involved in regulation of many inflammatory and metabolic processes [8]. Insulin resistance, atherosclerosis and T2DM may be induced by abnormal adipose tissue endocrine function [9]. Abnormal levels of inflammatory cytokines among patients with T2DM cause endothelial cell dysfunction [10], that may be induced by factors as dyslipidemia, hyperinsulinemia and $\beta$-cell failure [11]. Insulin is an important regulator for vascular function [12-14].
As there is inconclusive data regarding the impact of life style modification upon adhesive molecules and depression among obese type 2 diabetic patients. Therefore, the study aimed to determine the impact of 12 weeks of weight reduction program on depression and adhesive molecules dysregulation in obese type 2 diabetic patients.

\section{Patients and Methods}

\section{Subjects}

One hundred obese Saudi subjects with T2DM, their body mass index (BMI) was 30 to $34 \mathrm{Kg} / \mathrm{m}^{2}$, exclusion criteria included smoking, hepatitis, renal failure, heart failure, pregnancy and respiratory failure. Consent form signed by all participants who were enrolled in two groups, group (A) received aerobic exercises and diet regimen, while group (B) was the control group received no intervention for three months. 


\section{Current Research in Diabetes \& Obesity Journal}

\section{Measurements}

Biomarkers of endothelial function measurements: Biomarkers of endothelial function included intercellular cell adhesion molecule-1 (ICAM-1), vascular cell adhesion molecule-1 (VCAM-1) and soluble E-selectin levels weremeasured from frozen blood plasma samples that are stored at $-80^{\circ} \mathrm{C}$. Also, ELISAs was used to measure soluble levels of ICAM-1, VCAM-1 and sE-selectin (GE Healthcare Amersham, Biotrak Easy ELISA), which employs the quantitative sandwich enzyme immunoassay technique.

Rosenberg self-esteem scale (RSES): Beck Depression Inventory (BDI) andProfile of Mood States (POMS) were measured to assess mood, psychological wellbeing and selfEsteem.

\section{Procedures}

All participants enrolled in two groups as following:

Aerobic exercise training: For group (A) participants completed a 3-months treadmill aerobic exercise.Training program included range motion and stretching exercises as a warming-up for five minutes, 30 minutes of aerobic exercise with intensity about $60-70 \%$ of the individual maximum heart rate followed by cooling down for 10 minutes[15]. Participants had 3 sessions /weekly for 12 weeks. Also, a diet regimen that provide low caloric diet of 1200 Kilocalories/day for 12 weeks.

The control group (group B): Received no intervention.

\section{Statistical Analysis}

The investigated parameters mean values in both groups were detected at the beginning and at the end of the study and they were compared by student paired " $t$ " test. While, the unpaired" test was used in comparison between the two groups $(\mathrm{P}<0.05)$.

\section{Results}

The baseline criteria comparison proved that the two groups were homogenous as there were no significant differences betweenboth groups (Table 1). Results of group (A) stated that mean values of BMI, ICAM-1, VCAM-1, E-selectin, BDI and POMS significantly decreasedin addition to significant increase in the mean value of RSES as result of weight reducing program (Table 2), where parameters of group (B) displayed non-significant variations (Table 3). Additionally, no significant differences found between both groups in all parameters (Table 4$)(\mathrm{P}<0.05)$.

Table 1: Baseline allparticipants criteria.

\begin{tabular}{|c|c|c|c|}
\hline & Group (A) & Group (B) & Significance \\
\hline Age (year) & $47.53 \pm 4.26$ & $49.24 \pm 5.17$ & $P>0.05$ \\
\hline BMI $\left(\mathrm{kg} / \mathrm{m}^{2}\right)$ & $34.12 \pm 3.97$ & $33.86 \pm 4.12$ & $\mathrm{P}>0.05$ \\
\hline Duration of diabetes (years) & $10.14 \pm 2.19$ & $9.23 \pm 2.55$ & $\mathrm{P}>0.05$ \\
\hline SBP (mmHg) & $146.47 \pm 10.11$ & $144.53 \pm 9.28$ & $P>0.05$ \\
\hline DBP (mmHg) & $88.16 \pm 6.21$ & $87.27 \pm 5.93$ & $\mathrm{P}>0.05$ \\
\hline Total Cholesterol (mg/dL) & $197.24 \pm 20.13$ & $194.88 \pm 19.13$ & $\mathrm{P}>0.05$ \\
\hline HDL-C (mg/dL) & $44.16 \pm 5.37$ & $45.63 \pm 5.72$ & $\mathrm{P}>0.05$ \\
\hline Triglycerides (mg/dL) & $141.72 \pm 15.18$ & $138.64 \pm 13.95$ & $\mathrm{P}>0.05$ \\
\hline HBA1c (\%) & $9.23 \pm 2.62$ & $9.15 \pm 2.38$ & $P>0.05$ \\
\hline Glucose (mmol/L) & $5.46 \pm 1.21$ & $5.33 \pm 1.47$ & $P>0.05$ \\
\hline Insulin (pmol/L) & $20.51 \pm 4.25$ & $19.73 \pm 4.82$ & $\mathrm{P}>0.05$ \\
\hline
\end{tabular}

BMI: Body Mass Index; SBP: Systolic Blood Pressure; DBP: Diastolic Blood Pressure;HDL-C: High Density Lipoprotein Cholesterol; HBA1c:Glycosylated Hemoglobin

Table 2: Mean value and significance of parameters in group (A) before and at the end of the study.

\begin{tabular}{|c|c|c|c|c|}
\hline \multirow{2}{*}{} & \multicolumn{2}{|c|}{ Mean +SD } & \multirow{2}{*}{ T-Value } & \multirow{2}{*}{ Significance } \\
\cline { 2 - 4 } & Pre & Post & 6.81 & $\mathrm{P}<0.05$ \\
\hline BMI $\left(\mathrm{kg} / \mathrm{m}^{2}\right)$ & $34.12 \pm 3.97$ & $27.34 \pm 3.56^{*}$ & 8.12 & $\mathrm{P}<0.05$ \\
\hline ICAM-1 $(\mathrm{ng} / \mathrm{ml})$ & $91.43 \pm 10.21$ & $80.72 \pm 8.22^{*}$ & 10.38 & $\mathrm{P}<0.05$ \\
\hline VCAM-1(ng $/ \mathrm{ml})$ & $812.41 \pm 33.56$ & $736.85 \pm 27.46^{*}$ & 7.83 & $\mathrm{P}<0.05$ \\
\hline E-selectin(ng/ml) & $15.82 \pm 2.53$ & $12.19 \pm 2.45^{*}$ & 6.15 & $\mathrm{P}<0.05$ \\
\hline RSES & $20.37 \pm 3.14$ & $26.82 \pm 3.27^{*}$ & 5.71 & $\mathrm{P}<0.05$ \\
\hline BDI & $8.13 \pm 2.16$ & $4.86 \pm 1.74^{*}$ & 6.32 & $\mathrm{P}<0.05$ \\
\hline POMS & $24.17 \pm 4.32$ & $18.51 \pm 3.76^{*}$ & & \\
\hline
\end{tabular}

BMI: Body Mass Index; ICAM-1: Inter-Cellular Adhesion Molecule; VCAM-1: Vascular Cell Adhesion Molecule; RSES: Rosenberg Self-Esteem Scale; BDI: Beck: Depression Inventory; POMS: Profile of Mood States

${ }^{*}$ ) indicates a significant difference, $\mathrm{P}<0.05$ 


\section{Current Research in Diabetes \& Obesity Journal}

Table 3: Mean value and significance of parameters in group (B) before and at the end of the study.

\begin{tabular}{|c|c|c|c|c|}
\hline \multirow{2}{*}{} & Pre & Post & \multirow{2}{*}{ T-Value } & \multirow{2}{*}{ Significance } \\
\cline { 2 - 4 } & $33.86 \pm 4.12$ & $34.12 \pm 3.98$ & 1.46 & P $>0.05$ \\
\hline BMI $\left(\mathrm{kg} / \mathrm{m}^{2}\right)$ & $90.74 \pm 9.88$ & $91.26 \pm 9.85$ & 1.72 & $\mathrm{P}>0.05$ \\
\hline ICAM-1 $(\mathrm{ng} / \mathrm{ml})$ & $807.92 \pm 34.15$ & $815.78 \pm 33.69$ & 1.98 & $\mathrm{P}>0.05$ \\
\hline VCAM-1 $(\mathrm{ng} / \mathrm{ml})$ & $15.83 \pm 2.42$ & $16.12 \pm 2.47$ & 1.15 & $\mathrm{P}>0.05$ \\
\hline E-selectin(ng/ml) & $20.61 \pm 3.54$ & $19.85 \pm 3.72$ & 1.31 & $\mathrm{P}>0.05$ \\
\hline RSES & $7.95 \pm 1.92$ & $7.98 \pm 1.95$ & 0.95 & $P>0.05$ \\
\hline BDI & $23.87 \pm 4.25$ & $24.21 \pm 4.28$ & 1.22 & $P>0.05$ \\
\hline POMS & & & & \\
\hline
\end{tabular}

BMI: Body Mass Index; ICAM-1: Inter-Cellular Adhesion Molecule; VCAM-1: Vascular Cell Adhesion Molecule; RSES: Rosenberg Self-Esteem Scale; BDI: Beck: Depression Inventory; POMS: Profile of Mood States

$\mathrm{P}<0.05$

Table 4: Mean value and significance of parameters in group (A) and group (B) at the end of the study.

\begin{tabular}{|c|c|c|c|c|}
\hline \multirow{2}{*}{} & \multicolumn{2}{|c|}{ Mean +SD } & \multirow{2}{*}{ T-Value } & \multirow{2}{*}{ Significance } \\
\cline { 2 - 5 } & Group (A) & Group (B) & 4.25 & $\mathrm{P}<0.05$ \\
\hline BMI $\left(\mathrm{kg} / \mathrm{m}^{2}\right)$ & $27.34 \pm 3.56^{*}$ & $34.12 \pm 3.98$ & 6.73 & $\mathrm{P}<0.05$ \\
\hline ICAM-1 $(\mathrm{ng} / \mathrm{ml})$ & $80.72 \pm 8.22^{*}$ & $91.26 \pm 9.85$ & 8.13 & $\mathrm{P}<0.05$ \\
\hline VCAM-1 $(\mathrm{ng} / \mathrm{ml})$ & $736.85 \pm 27.46^{*}$ & $815.78 \pm 33.69$ & 6.27 & $\mathrm{P}<0.05$ \\
\hline E-selectin(ng/ml) & $12.19 \pm 2.45^{*}$ & $16.12 \pm 2.47$ & 5.11 & $\mathrm{P}<0.05$ \\
\hline RSES & $26.82 \pm 3.27^{*}$ & $19.85 \pm 3.72$ & 4.85 & $\mathrm{P}<0.05$ \\
\hline BDI & $4.86 \pm 1.74^{*}$ & $7.98 \pm 1.95$ & 5.13 & $\mathrm{P}<0.05$ \\
\hline POMS & $18.51 \pm 3.76^{*}$ & $24.21 \pm 4.28$ & & \\
\hline
\end{tabular}

BMI: Body Mass Index; ICAM-1: Inter-Cellular Adhesion Molecule; VCAM-1: Vascular Cell Adhesion Molecule; RSES: Rosenberg Self-Esteem Scale; BDI: Beck: Depression Inventory; POMS: Profile of Mood States

$\left({ }^{*}\right)$ indicates a significant difference, $P<0.05$

\section{Discussion}

Cardiovascular dysfunction is the principal cause for higher mortality rate worldwide among diabetics [16]. The ideal approach for weight reduction is to combine exercise and diet regimen to modulate biochemical parameters of obese subjects [17-19]. Moreover, weight reduction improves psychological background. The principal finding of this study was that weight loss ameliorate adhesive molecules (ICAM-1 VCAM-1 and E-selectin) as well as improvement in depression of patients with T2DM.

Regarding psychological effects of weight loss, this study proved that life style modification (aerobic exercise and diet regimen) significantly decreased BDI \& POMS and increased RSES, there are several studies proved that weight loss improved these psychological parameters [20-24]. While,Grave et al.[20]enrolled 500 obese individuals in oneyear weight reducing program and found that weight reduction improved psychological parameters. Moreover, another long-term weight reducing program for up to five years improved cardiovascular status in type 2 diabetics[21]. Also, Imayama et al. [22] concluded that one year weight reduction program had a positive impact on quality of life and psycho-social background of the participants. In addition, Wycherley et al. [23]proved that diet regimen with or without resisted exercise training modulates biochemical and psychological parameters of obese T2DM patients. Similarly, Faulconbridge et al. [24] mentioned that weight reduction is associated with mood improvement of depressed patients.

Concerning adhesive molecules, this study proved that life style modification (aerobic exercise and diet regimen) significantly improved ICAM-1 VCAM-1 and E-selectin because of weight reduction, these findings are online with several previous studies [25-28]. However, Sharman \& Volek[29]found that 6 week diet regimen reduced plasma ICAM-1. While, Forsythe et al. [30] stated that 3 months diet regimen modulated dyslipidemia and reduction in E-selectin and ICAM. Moreover, Thomson et al. [31] obtained modulation in parameters of endothelial function after 20 weeks of a high-protein energy-restricted diet and/ or exercise in women with polycystic ovary syndrome. Finally, GarantyBogacka et al. [32] applied a 1 year program of exercise training and diet regimen which reduced adhesive molecules ofobese adolescents. 


\section{Current Research in Diabetes \& Obesity Journal}

\section{Conclusion}

Life style modification led to weight loss which modulates depression and adhesive molecules in obese type 2 diabetics.

\section{Acknowledgment}

Author thanks Prof. Shehab M. Abd El-kader for his valuable practical share in this research.

\section{References}

1. Organization WH (2010) Prevalence of diabetes Worldwide.

2. Leiter LA, Fitchett DH, Gilbert RE, Gupta M, Mancini GB, et al. (2011) Identification and management of cardiometabolic risk in Canada: a position paper by the cardiometabolic risk working group (executive summary). Can J Cardiol 27(2):124-131.

3. DeFronzo RA (2010) Insulin resistance, lipotoxicity, type 2 diabetes and atherosclerosis: the missing links. The Claude Bernard Lecture 2009. Diabetologia53 (7): 1270-1287.

4. Seshasai SR, Kaptoge S, Thompson A, Di Angelantonio E, Gao P, et al. (2011) Diabetes mellitus, fasting glucose, and risk of cause-specific death. N Engl J Med 364 (9): 829-841.

5. Besler C, Luscher TF, Landmesser U (2012) Molecular mechanisms of vascular effects of High-density lipoprotein: alterations in cardiovascular disease. EMBO Mol Med 4(4): 251e68.

6. Farbstein D, Levy AP (2012) HDL dysfunction in diabetes: causes and possible treatments. Expert Rev Cardiovasc Ther 10(3): 353-361.

7. Chen G, McAlister F, Walker R, Hemmelgarn B, Campbell N (2011) Cardiovascular outcomes in Framingham participants with diabetes: the importance of blood pressure. Hypertension 57(5):891-897.

8. Simon G, Von Korff M, Saunders K, Miglioretti D, Crane P,et al. (2006) Association between obesity and psychiatric disorders in the US adult population. Arch Gen Psychiatry63(7): 824-830.

9. Mather A, Cox B, Enn M, Sareen J (2009) Associations of obesity with psychiatric disorders and suicidal behaviors in a nationally representative sample. J Psychosom Res66(4): 277-285.

10. Cersosimo E, DeFronzo RA(2006)Insulin resistance and endothelial dysfunction: the road map to cardiovascular diseases. Diabetes Metab Res Rev22(6): 423-436.

11. Endemann DH, Schiffrin EL(2004)Endothelial dysfunction. J Am Soc Nephrol15(8): 1983-1992.

12. Gómez JM, Sahún M, Vila R, Domènech P, Catalina P, et al. (2007) Elevation of E-selectin concentrations may correlate with potential endothelial dysfunction in individuals with hypopituitarism during therapy with growth hormone. CurrNeurovasc Res 4(1): 55-62.

13. American Diabetes Association (2010) Diagnosis and classification of diabetes mellitus. Diabetes Care33(Suppl1): S62-S69.

14. Palmeira A, Branco T, Martins S, Minderico C, Silva M,etal. (2010) Change in body image and psychological well-being during behavioral obesity treatment: Associations with weight loss and maintenance. Body Image7(3): 187-193.

15. Robergs R, Landwehr R (2002) The surprising history of the "HR $\mathrm{max}_{\max }=220$-age" equation. J ExercPhysiol Online 5(2): 1-10.

16. Almdal T, Scharling H, Jensen JS, Vestergaard H (2004)The independent effect of type 2 diabetes mellitus on ischemic heart disease, stroke, and death: a population-based study of 13000 men and women with 20 years of follow- up. ArchInternMed164 (13): 1422-1426.
17. Balagopal P, George D, Patton N, Yarandi H, Roberts WL, et al. (2005) Lifestyle-only intervention attenuates the inflammatory state associated with obesity: a randomized controlled study in adolescents. J Pediatr 146(3): 342-348.

18. Roth CL, Kratz M, Ralston MM, Reinehr T (2011) Changes in adiposederived inflammatory cytokines and chemokines after successful lifestyle intervention in obese children. Metabolism 60(4): 445-452.

19. Roberts CK, Chen AK, Barnard RJ (2007) Effect of a short-term diet and exercise intervention in youth on atherosclerotic risk factors. Atherosclerosis 191(1): 98-106.

20. Grave R, Calugi S, Petroni M, Di Domizio S, Marchesini G (2010) Weight management, psychological distress and binge eating in obesity. A reappraisal of the problem. Appetite 54(2): 269-273.

21. Lau DC, Teoh H (2013) Benefits of modest weight loss on the management of type 2 diabetes mellitus. Can J Diabetes 37(2): 128134.

22. Imayama I, Alfano C, Kong A, FosterSchubert K, Bain C, etal. (2011) Dietary weight loss and exercise interventions effects on quality of life in overweight/obese postmenopausal women: a randomized controlled trial. Int J Behav Nutr Phys Act8: 118-129.

23. Wycherley T, Clifton P, Noakes M, Brinkworth G (2014) Weight loss on a structured hypocaloric diet with or without exercise improves emotional distress and quality of life in overweight and obese patients with type 2 diabetes.Journal of Diabetes Investigation5(1): 94-98.

24. Faulconbridge L, Wadden T, Rubin R, Walkup A, Fabricatore A, et al. (2009) One-year changes in weight and symptoms of depression in depressed vs. non-depressed individuals in the Look AHEAD study. Obesity 17(Suppl 2):576.

25. Keogh JB, Brinkworth GD, Noakes M, Belobrajdic DP, Buckley JD, et al. (2008) Effects of weight loss from a very-low-carbohydrate diet on endothelial function and markers of cardiovascular disease risk in subjects with abdominal obesity.Am J Clin Nutr 87(3): 567-576.

26. Hamdy O, Ledbury S, Mullooly C, Jarema C, Porter S, et al. (2003) Lifestyle modification improves endothelial function in obese subjects with the insulin resistance syndrome. Diabetes Care 26(7): 2119-2125.

27. Wegge JK, Roberts CK, Ngo TH, Barnard RJ (2004) Effect of diet and exercise intervention on inflammatory and adhesion molecules in postmenopausal women on hormone replacement therapy and at risk for coronary artery disease. Metabolism 53(3): 377-381.

28. Rector RS, Turk JR, Sun GY, Guilford BL, Toedebusch BW, et al. (2006) Short-term lifestyle modification alters circulating biomarkers of endothelial health in sedentary, overweight adults. Appl PhysiolNutrMetab 31(5): 512-517.

29. Sharman MJ, Volek JS (2004) Weight loss leads to reductions in inflammatory biomarkers after a very-low-carbohydrate diet and a low-fat diet in overweight men. Clin Sci (Lond) 107(4): 365-369.

30. Forsythe CE, Phinney SD, Fernandez ML, Quann EE, Wood RJ, et al. (2008) Comparison of low fat and low carbohydrate diets on circulating fatty acid composition and markers of inflammation. Lipids 43(1): 65-77.

31. Thomson RL, Brinkworth GD, Noakes M, Clifton PM, Norman RJ, et al. (2012) The effect of diet and exercise on markers of endothelial function in overweight and obese women with polycystic ovary syndrome. Hum Reprod27 (7): 2169-2176.

32. Garanty Bogacka B, Rać M, Syrenicz M, Gębala A, Walczak M, etal. (2012) Changes in serum adipocytokines and inflammatory biomarkers following one-year of exercise training in obese adolescents. J Diabetes Metab 3(7): 212-217. 

CC Commons Attribution 4.0 Licens

DOI: 10.19080/CRDOJ.2018.07.555724

\section{Your next submission with Juniper Publishers} will reach you the below assets

- Quality Editorial service

- Swift Peer Review

- Reprints availability

- E-prints Service

- Manuscript Podcast for convenient understanding

- Global attainment for your research

- Manuscript accessibility in different formats

( Pdf, E-pub, Full Text, Audio)

- Unceasing customer service

Track the below URL for one-step submission https://juniperpublishers.com/online-submission.php 